\title{
Meat properties and fatty acid profile of swine fed cashew bagasse bran in qualitative food restriction program
}

\author{
José Aparecido Moreira ${ }^{1}$, Rafael Leandro Ramos de Oliveira ${ }^{2}$, Apauliana Daniela Lima da \\ Silva ${ }^{2}$, Lorena Cunha Mota ${ }^{3}$, Bruna Maria Emerenciano das Chagas ${ }^{1}$, Andreza Lourenço \\ Marinho $^{1^{*}}$, Janete Gouveia de Souza ${ }^{1}$, Elisanie Neiva Magalhães Teixeira ${ }^{1}$ \\ 1 Universidade Federal do Rio Grande do Norte, Unidade Acadêmica Especializada em Ciências Agrárias, Distrito de Jundiaí, Macaíba, RN, \\ Brasil. \\ 2 Universidade Federal do Rio Grande do Norte, Programa de Pós-graduação em Produção Animal, Natal, RN, Brasil. \\ ${ }^{3}$ Universidade Federal de Goiás, Programa de Pós-graduação em Zootecnia, Goiânia, GO, Brasil.
}

\begin{abstract}
The purpose of this study was to evaluate the effects of qualitative dietary restriction diet on carcass characteristics, meat quality, fatty acid profile, and performance of finishing pigs fed diets containing cashew bagasse bran. Forty pigs (20 females and 20 males) with initial weight of $60.00 \pm 5.24 \mathrm{~kg}$ of body weight (BW) were used. The diets were formulated with corn, soybean meal, cashew bagasse bran, vegetable oil, and mineral and vitamin mixture for finishing pigs. The experimental design was in randomized blocks with five treatments and four replicates, with two animals per experimental unit, one of each sex. Parameters related to performance, carcass characteristics, meat quality, and fatty acids profiles were used. The treatments used in the experiment did not affect feed intake and daily weight gain; however, in relation to feed conversion, a linear effect was observed with the increase of cashew bagasse bran levels in the diet. The same effects were also observed in carcass yield, backfat thickness, and fat area. The meat:fat ratio increased linearly with the increase of fiber in the diet. The level of $22.5 \%$ of cashew bagasse bran in finishing pig diets is recommended.
\end{abstract}

Key Words: alternative feed, carcass yield, cashew bran, digestible fiber

\section{Introduction}

Cashew bagasse bran (CBB) is characterized as a medium-value fiber and low-energy food containing $88.70 \%$ dry matter, $4.15 \%$ ether extract, $14 \%$ crude protein, $12.07 \%$ crude fiber, $1,123 \mathrm{kcal} / \mathrm{kg}$ of digestible energy, and $1,051 \mathrm{kcal} / \mathrm{kg}$ of metabolizable energy (Farias et al., 2008). It is a byproduct of the juice and cashew processing industry; after drying and ground, CBB can be used in animal feed (Farias et al., 2008).

The states of Ceará, Piauí, and Rio Grande do Norte are the largest producers of cashew nuts in Brazil, with chestnut and cashew juice normally marketed, but about $85 \%$ of the bagasse is usually wasted (Riozi et al., 2011). This feed contains a good nutritive value and is rich in nutrients, and due to its fibrous characteristic, it can be incorporated in the diets in qualitative restriction.

Received: July 18, 2017

Accepted: November 24, 2017

*Corresponding author: andrezazte@hotmail.com

Copyright (C) 2018 Sociedade Brasileira de Zootecnia. This is an Open Access article distributed under the terms of the Creative Commons Attribution License (http://creativecommons.org/licenses/by/4.0/), which permits unrestricted use, distribution, and reproduction in any medium, provided the original work is properly cited.
The use of food restriction in the finishing phase is aimed at reducing the deposition of subcutaneous fat and increasing the lean tissue in the carcass, whether quantitative or qualitative (Moreira et al., 2007). In the qualitative restriction, low-cost fibrous foods are used, in which the filling of the digestive system of the animal increases satiety and guarantees animal welfare (Fraga et al., 2008).

What is important in the study of dietary strategies in the feeding of pigs with the use of fibers is to know the capacity of ingestion and the type of fibrous material, so that no digestive disorders that compromise animal welfare occur.

Albuquerque et al. (2009) reported that diets with different formulations cause modifications in the fatty acid composition of the meat. The main saturated fatty acids (SFA) are palmitic, stearic, myristic, and lauric; and monounsaturated are oleic and palmitoleic. Linoleic, linolenic, and arachidonic acids are the main polyunsaturated fatty acids (PUFA) (Rhee et al., 1988). Among the fatty acids of animal tissue, the most undesirable are the myristic, palmitic, and lauric acids because they present hypercholesterolemic effect. Stearic acid has no effect because it is converted into oleic acid in the liver (French et al., 2003). Alpha-linolenic and 
linoleic acids are PUFA, considered essential because they are not synthesized by body cells (Perini et al., 2010). In this context, the objective of this study was to evaluate the effects of the qualitative food restriction on the performance, meat quality, and fatty acid profile of pigs in the finishing phase.

\section{Material and Methods}

This research was conducted and authorized by the institutional ethics committee on animal use, case number 004/2011. The experiment was conducted in Macaíba,

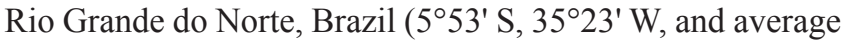
altitude of $40 \mathrm{~m}$ ).

Forty hybrid pigs ( 20 castrated males and 20 females) with mean initial weight of $60.00 \pm 5.24 \mathrm{~kg}$ of body weight (BW) were used. The animals were housed in stalls with simple feeders and pacifier-type drinkers.

The maximum and minimum temperatures, relative humidity, and temperature and humidity index of the experimental period were 32.4 and $24{ }^{\circ} \mathrm{C}, 84 \%$, and 80 , respectively.

The experimental design consisted of randomized block with five treatments and four replicates, with two animals per experimental unit. The diets were formulated according to the recommendations of Rostagno et al. (2005) for medium-performance pigs, except for the energy level. Cashew bagasse bran (Table 1) was included in the experimental diets replacing corn and soybean meal, characterizing the qualitative food restriction.

The treatments were composed of experimental diets formulated with corn, soybean meal, wheat, soybean oil, and mineral and vitamin mixture for finishing pigs, with different levels of inclusion of cashew bagasse bran (0.0, 7.5, 15.0, 22.5, and 30.0\%) (Table 2).

Table 1 - Chemical composition of cashew bagasse bran

\begin{tabular}{lc}
\hline Ingredient (\%) & \\
\hline Dry matter & 88.96 \\
Crude protein & 15.98 \\
Gross energy (kcal/kg) & 4,081 \\
Ether extract & 2.30 \\
Neutral detergent fiber & 68.14 \\
Acid detergent fiber & 41.15 \\
Fatty acid composition analysis (\% calculated total) & \\
Myristic (C14:0) & 0.105 \\
Palmitic (C16:0) & 20.90 \\
Palmitoleic (C16:1) & 3.50 \\
Stearic (C18:0) & 2.447 \\
Oleic (C18:1) & 60.55 \\
Linoleic (C18:2) & 5.89 \\
Linolenic (C18:3) & 1.18 \\
\hline
\end{tabular}

The animals received water and feed at will and were weighed at the beginning and at the end of the experiment to evaluate the animal performance.

At the end of the experimental period, which lasted 35 days, the animals (95 $\pm 7.42 \mathrm{~kg} \mathrm{BW})$ were subjected to a fasting of solids. The animals were transported to the abattoir where they remained in pre-slaughter rest for $3 \mathrm{~h}$, totaling $12 \mathrm{~h}$ of fasting.

The castrated male pigs were desensitized by electric stunning, then bled, depilated, and eviscerated. The carcasses were sawn longitudinally in the middle to perform the evaluation procedures, and the measurements were performed in the left half carcass. Initial $\mathrm{pH}$ values (45 min after slaughter) and warm carcass weight (WCW) were measured. With the WCW, it was possible to calculate the carcass yield (CY) by multiplying the WCW by 100 and dividing by the final weight of the animal. After the evaluations, the carcasses were placed in a cold room for $24 \mathrm{~h}$ at a temperature of $2 \pm 1{ }^{\circ} \mathrm{C}$. Carcass parameters

Table 2 - Composition of experimental feeds given to pigs in the finishing phase

\begin{tabular}{|c|c|c|c|c|c|}
\hline \multirow{2}{*}{ Ingredient } & \multicolumn{5}{|c|}{ Level of cashew bagasse bran ( $\%)$} \\
\hline & 0.0 & 7.5 & 15.0 & 22.5 & 30.0 \\
\hline Corn & 74.86 & 68.86 & 62.86 & 56.86 & 50.87 \\
\hline Soybean bran & 22.14 & 20.64 & 19.14 & 17.63 & 16.13 \\
\hline Commercial nucleus ${ }^{1}$ & 2.50 & 2.50 & 2.50 & 2.50 & 2.50 \\
\hline Soybean oil & 0.50 & 0.50 & 0.50 & 0.50 & 0.50 \\
\hline Total & 100 & 100 & 100 & 100 & 100 \\
\hline \multicolumn{6}{|l|}{ Calculated composition } \\
\hline Digestible energy $(\mathrm{kcal} / \mathrm{kg})$ & 3,400 & 3,268 & 3,134 & 3,000 & 2,866 \\
\hline Crude protein & 16.50 & 16.50 & 16.50 & 16.50 & 16.50 \\
\hline Digestible lysine & 0.69 & 0.67 & 0.64 & 0.61 & 0.59 \\
\hline Digestible methionine & 0.25 & 0.25 & 0.24 & 0.24 & 0.24 \\
\hline Digestible tryptophan & 0.16 & 0.15 & 0.14 & 0.13 & 0.12 \\
\hline Calcium & 0.69 & 0.69 & 0.69 & 0.69 & 0.69 \\
\hline Total phosphorus & 0.31 & 0.31 & 0.31 & 0.30 & 0.31 \\
\hline Available phosphorus & 0.14 & 0.13 & 0.14 & 0.13 & 0.14 \\
\hline Sodium & 0.17 & 0.17 & 0.17 & 0.16 & 0.17 \\
\hline Neutral detergent fiber & 11.68 & 15.89 & 20.11 & 24.32 & 28.53 \\
\hline Acid detergent fiber & 4.28 & 7.05 & 9.81 & 12.58 & 15.34 \\
\hline \multicolumn{6}{|c|}{ Analyzed composition of fatty acid ( $\%$ analyzed) } \\
\hline Myristic (C14:0) & 0.079 & 0.088 & 0.091 & 0.091 & 0.093 \\
\hline Palmitic (C16:0) & 17.72 & 17.90 & 17.59 & 17.40 & 17.16 \\
\hline Palmitoleic (C16:1) & 0.126 & 0.430 & 0.617 & 0.775 & 0.925 \\
\hline Stearic (C18:0) & 3.28 & 2.87 & 3.97 & 2.62 & 2.69 \\
\hline Oleic (C18:1) & 32.09 & 33.38 & 35.59 & 37.25 & 38.83 \\
\hline Linoleic (C18:2) & 44.65 & 43.17 & 40.23 & 39.09 & 38.10 \\
\hline Linolenic (C18:3) & 0.087 & 0.219 & 0.362 & 0.383 & 0.571 \\
\hline
\end{tabular}

${ }^{1}$ Guaranteed levels per kg of product: calcium (minimum), $240 \mathrm{~g}$; calcium (maximum), $245 \mathrm{~g}$; phosphorus (minimum), $25 \mathrm{~g}$; sodium (minimum), $55 \mathrm{~g}$; iron (minimum), $3,200 \mathrm{mg}$; copper (minimum), 5,000 mg; manganese (minimum), 1,280 mg; zinc (minimum), 2,400 mg; iodine (minimum), $25.50 \mathrm{mg}$; cobalt (minimum), $12.80 \mathrm{mg}$; selenium (minimum), $9.60 \mathrm{mg}$; vitamin A (minimum), $180 \mathrm{IU}$; vitamin D3 (minimum), 32,000 IU; vitamin E (minimum), $720 \mathrm{IU}$; vitamin K3 (minimum), $36 \mathrm{mg}$; vitamin B1 (minimum), $27 \mathrm{mg}$; vitamin B2 (minimum), $108 \mathrm{mg}$; niacin (minimum), $638 \mathrm{mg}$; pantothenic acid (minimum), $362 \mathrm{mg}$; vitamin B6 (minimum), $36 \mathrm{mg}$; folic acid (minimum), $18 \mathrm{mg}$; biotin (minimum), $1.80 \mathrm{mg}$; vitamin B12 (minimum), $580 \mathrm{mg}$; colistin, $200 \mathrm{mg}$; phytase $\mathrm{U} / \mathrm{g}$. 
(carcass length, backfat thickness, loin eye area, and fat area) were evaluated after this period, according to the Brazilian Carcass Classification Methods (ABCS, 1973), and the meat quality parameters (final $\mathrm{pH}$, color, and marbling) as recommended by Bridi and Silva (2009). Loin and lard samples were collected, packaged, identified, and frozen until the analyses were performed.

The carcass length was obtained with the aid of a braid and the measurement was performed from the cranial edge of the pubic symphysis to the ventral skull atlas of the atlas. The backfat thickness was measured at three points on the carcass (first rib, last rib, and between the last and penultimate lumbar vertebrae) with the aid of a pachymeter; then, the average fat thickness was calculated on the carcass. The depth of loin was performed with the aid of a pachymeter, in which the carcass was sawn at the last rib for exposure of the long dorsi muscle; in the same region, the drawings of the loin area and fat area were made in vegetal paper.

The $\mathrm{pH}$ measurements were performed on the longissimus dorsi muscle (at the last rib height), $45 \mathrm{~min}$ and $24 \mathrm{~h}$ after slaughter using a portable $\mathrm{pH}$ meter (Bridi and Silva, 2009). Meat color was measured using a color chart with a scale from 1 to 6 (Bridi and Silva, 2009), $24 \mathrm{~h}$ after slaughter.

To evaluate the fatty acid profile, the loin and backfat samples were thawed and ground in a microprocessor, and a 5-g aliquot was weighed, placed in a solution of chloroform, methane, and water, and shaken on a shaker table for $20 \mathrm{~min}$. Then, the samples with the solution were refrigerated for $12 \mathrm{~h}$ to separate the phases (water and fat). After $12 \mathrm{~h}$, the mixture was filtered in $2 \%$ sulfide solution, stored in an amber bottle, and frozen until esterification, according to the methods described by Bligh and Dyer (1959). Fatty acids extracted from loin and backfat were esterified according to the method of Hartman and Lago (1973).

The determination of the fatty acids was obtained by gas chromatography (Thermo Scientific - CG/FID - FOCUS) with a flame ionization detector and a Supelco SPTM SPTM - 2560 capillary column $(100 \mathrm{~m} \times 0.25 \mathrm{~mm} \times 0.2 \mu \mathrm{m})$.
The injector and detector temperatures were 270 and $230^{\circ} \mathrm{C}$, respectively. The column heating program was started at $40{ }^{\circ} \mathrm{C}$ for $3 \mathrm{~min}$, then $180^{\circ} \mathrm{C}$ for $5 \mathrm{~min}$ at a rate of $10^{\circ} \mathrm{C} / \mathrm{min}$, 180 to $220^{\circ} \mathrm{C}$ for $3 \mathrm{~min}$ at a rate of $10^{\circ} \mathrm{C} / \mathrm{min}$, and 220 to $240{ }^{\circ} \mathrm{C}$ for $25 \mathrm{~min}$ at a rate of $20^{\circ} \mathrm{C} / \mathrm{min}$. The injector volume was $1 \mu \mathrm{L}$ with a 1:10 Split reaction. The carrier gas used was nitrogen.

Peak identification and quantification were done by comparing the retention time and peak area of the samples with the methyl esters of fatty acid pattern (Supelco 37 components FAMEs Mix, Ref. 47885-U). The collected data were subjected to an orthogonal polynomial regression analysis and a $\mathrm{t}$ test, according to procedures of SAS software (Statistical Analysis System, version 9.0).

\section{Results}

When evaluating the performance parameters, it was verified that the increasing inclusion levels of $\mathrm{CBB}$ did not affect $(\mathrm{P}>0.05)$ the daily dietary intake (DDI) and the daily weight gain $(\mathrm{DWG})$; however, a linear increase $(\mathrm{P}<0.05)$ in feed conversion was observed as the CBB level in the diet increased (Table 3).

The parameters of slaughter weight, carcass length, loin weight, leg yield, loin eye area, $\mathrm{pH}$, and muscle color were not affected $(\mathrm{P}>0.05)$ by CBB inclusion levels (Table 4$)$.

In the evaluations performed on the carcass, it was observed that the carcass yield decreased linearly $(\mathrm{P}<0.05)$, while the fiber content increased as a function of $\mathrm{CBB}$ inclusion levels.

Analyzing the effect of increasing levels of CBB, there was a significant linear reduction $(\mathrm{P}<0.05)$ in backfat thickness and in the fat area of finishing pigs, and the meat: fat ratio of the carcass increased linearly $(\mathrm{P}<0.05)$.

Regarding the evaluation of the fatty acid profile of the subcutaneous fat and longissimus dorsi muscle, no differences $(\mathrm{P}>0.05)$ were observed in the contents of myristic, palmitoleic, oleic, and linolenic fatty acids, as well as in the linoleic and arachidonic acids of longissimus dorsi when the animals were fed different CBB levels (Table 5).

Table 3 - Average values of the performance test of finishing pigs fed diets containing cashew bagasse bran

\begin{tabular}{|c|c|c|c|c|c|c|c|}
\hline \multirow{2}{*}{ Variable } & \multicolumn{5}{|c|}{ Level of cashew bagasse bran (\%) } & \multirow{2}{*}{ P-value } & \multirow{2}{*}{ SEM } \\
\hline & 0 & 7.5 & 15 & 22.5 & 30 & & \\
\hline Daily feed intake (kg) & 2.622 & 2.702 & 2.975 & 3.027 & 2.690 & 0.4216 & 0.353 \\
\hline Daily weight gain (kg) & 0.869 & 0.876 & 0.900 & 0.867 & 0.789 & 0.4948 & 0.154 \\
\hline Feed conversion $*$ & 3.01 & 3.15 & 3.33 & 3.54 & 3.42 & 0.0067 & 0.245 \\
\hline
\end{tabular}


Table 4 - Effects of different inclusion levels of cashew bagasse bran on carcass traits of pigs in finishing phase

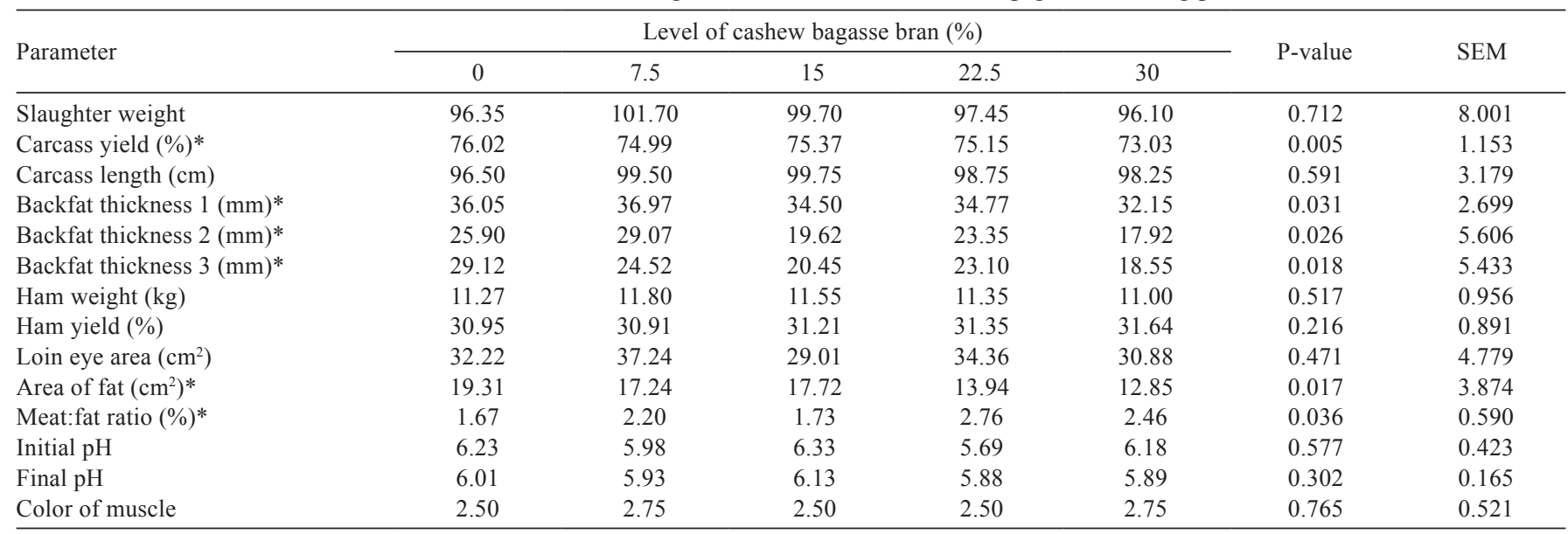

SEM - standard error of the mean.

* Linear effect $(\mathrm{P}<0.05)$.

Table 5 - Fatty acid profile in subcutaneous fat area and longissimus dorsi muscle of castrated finishing male pigs fed different levels of cashew bagasse bran

\begin{tabular}{|c|c|c|c|c|c|c|c|}
\hline \multirow{2}{*}{ Fatty acid } & \multicolumn{5}{|c|}{ Level of cashew bagasse bran $(\%)$} & \multirow{2}{*}{ P-value } & \multirow{2}{*}{ SEM } \\
\hline & 0 & 7.5 & 15 & 22.5 & 30 & & \\
\hline \multicolumn{8}{|c|}{ Subcutaneous fat area } \\
\hline Myristic (C14:0) & 1.57 & 1.55 & 1.54 & 1.51 & 1.55 & 0.992 & 0.193 \\
\hline Palmitoleic (C16:1) & 0.60 & 0.64 & 0.75 & 0.58 & 0.67 & 0.564 & 0.151 \\
\hline Oleic (C18:1) & 38.04 & 37.23 & 37.61 & 39.28 & 38.14 & 0.409 & 1.490 \\
\hline Linoleic $(\mathrm{C} 18: 2)^{*}$ & $13.66 \mathrm{a}$ & $15.37 \mathrm{ab}$ & $15.42 \mathrm{ab}$ & $15.83 \mathrm{ab}$ & $16.70 \mathrm{~b}$ & 0.325 & 1.937 \\
\hline Linolenic (C18:3) & 0.72 & 0.62 & 0.68 & 0.73 & 0.61 & 0.630 & 0.135 \\
\hline Arachidonic (C20:4)* & $0.16 \mathrm{a}$ & $0.22 \mathrm{ab}$ & $0.15 \mathrm{a}$ & $0.24 \mathrm{~b}$ & $0.22 \mathrm{ab}$ & 0.136 & 0.053 \\
\hline \multicolumn{8}{|c|}{ Longissimus dorsi muscle } \\
\hline Myristic (C14:0) & 1.24 & 1.55 & 1.16 & 1.67 & 1.50 & 0.909 & 0.772 \\
\hline Palmitoleic (C16:1) & 1.91 & 1.54 & 2.11 & 1.85 & 1.64 & 0.930 & 0.996 \\
\hline Oleic (C18:1) & 26.11 & 30.01 & 24.49 & 30.24 & 23.46 & 0.438 & 6.208 \\
\hline Linoleic (C18:2) & 22.23 & 18.65 & 23.53 & 18.62 & 21.47 & 0.675 & 5.700 \\
\hline Linolenic (C18:3 & 0.35 & 0.34 & 0.40 & 0.41 & 0.48 & 0.962 & 0.287 \\
\hline Arachidonic (C20:4) & 4.54 & 4.31 & 5.40 & 5.96 & 4.00 & 0.848 & 2.812 \\
\hline
\end{tabular}

SEM - standard error of the mean.

* Means followed by lowercase letters in the line are different among themselves $(\mathrm{P}<0.05)$ by the " $\mathrm{t}$ " test.

In relation to linoleic and arachidonic fatty acids, a significant difference $(\mathrm{P}<0.05)$ was observed in the amount deposited in the subcutaneous fat (backfat); it was also verified that the animals that consumed the ration with $30 \%$ CBB deposited $18.2 \%$ more linoleic acid than those consuming ration without bran, and those that consumed the ration of the treatment with $15 \%$ bran deposited, respectively, 33.3 and $37.5 \%$ less arachidonic acid than the animals in the other treatments valuated.

\section{Discussion}

The results concerning the animal performance obtained in this experiment are in agreement with the weight gain, with the studies carried out by Farias et al. (2008), who studied the increasing levels of cashew pseudofruit in the feeding of growing pigs and also did not observe effects for this variable; however, in relation to feed intake, the data differ as, for growing pigs, the researchers observed higher intake with the inclusion of $20 \%$ of bran in the diet. According to the authors, a nutritional imbalance of the diets could have occurred as a function of the digestibility of the cashew pseudofruit; thus, to supplement the deficiency, the animals increased the intake.

Schneeman (1982) reported that fiber inclusion in the diet may result in increased desquamation of the intestinal mucosa, increased mucus production, and increased intestinal peristalsis, restricting the permanence of dietary nutrients in the digestive tract, affecting absorption and, consequently, the core of animal satiety, leading to a compensatory increase in feed intake. 
Voluntary feed intake can also be affected by caloric increase, feed energy level, and digestive tract distention, and in finishing pigs, intake undergoes intervention of energy intake (Rao et al., 2006).

Although the experimental diets presented decreasing levels of energy, no effects were observed for feed intake and weight gain. However, feed conversion worsened linearly; this shows that, although the animals consumed the feed normally, this intake was not enough to ensure better performance, reflecting the reduced level of energy in the diets detected in the feed conversion assessment.

The results obtained with the carcass parameters and meat quality are consistent with some studies involving energy deficit in pig diets. According to Watanabe et al. (2010), due to the standardization of body weight, the carcass parameters are hardly influenced by the treatments. In a study with citrus pulp in feed for finishing pigs, the authors reported a linear reduction in carcass yield, similar to that observed in this experiment. The authors reported that this observed difference is probably due to the variation in the weight of the digestive tract organs, since a higher weight of the organs was observed in the animals that consumed a higher level of citrus pulp in the diet.

The thickness variables of backfat and the fat content were affected by the food restriction, as the effect was directly proportional to the energy level used in the diet, since the inclusion of increasing levels of pseudofruit bran in the diets resulted in a reduction in the energy level.

Reducing the fat deposition rate in the carcass is a characteristic desired by the industry and the final consumer, and it is necessary to seek alternatives to obtain this result, especially for finishing and post-finishing pigs. This result corroborates those obtained by Barbosa et al. (2003), who also observed a linear reduction in backfat thickness by increasing feed restriction levels $(0,5,10$, and $15 \%)$ in finishing pig diets.

Another favorable response to the use of food restriction was the meat:fat ratio that increased with the increasing levels of cashew bran inclusion in the diets, with data similar to those observed by Pinheiro et al. (2013). According to Louvandini et al. (2006) and Zangeronimo et al. (2009), the variables deposition of meat and fat are influenced by several factors, among them we can highlight the breeding and formulation of the diets, as well as the ingredients used.

Linoleic fatty acids are essential in animal diets, acting as precursors of other PUFA of the n- 6 series. These fatty acids of the n- 6 and n-3 series are obtained through diet or synthesized by the body from linoleic and $\alpha$-linolenic acid by the action of the desaturase and elongase enzymes (Martin et al., 2006).

Pettigrew and Esnaola (2001) highlighted the relationship between linoleic acid isomers and fat deposition, especially in relation to the apparent antilipogenic action of those that contribute to leaner carcasses. However, Lebret and Mourot (1998) reported that the fat content of the carcass depends on the increase of fat content in the diet and on the degree of unsaturation.

A higher content of linoleic and arachidonic acids was observed in the subcutaneous fat among the animals that received $\mathrm{CBB}$. This result is characteristic of the experiments involving food restriction, since with the reduction of the fat rate deposition in the carcass, the content of some PUFA usually increases, as observed by Santos et al. (2008), who also observed a lower amount of fat in the carcass associated with the higher linoleic acid content, both in the longissimus dorsi muscle and in the subcutaneous fat in pigs.

This metabolic process is mediated by enzymes desaturase and elongase that participate in the formation of PUFA, $\mathrm{n}-6$, and $\mathrm{n}-3$, resulting in a metabolic competition between the two groups.

The concentrations of myristic (C14:0), palmitoleic (C16:1), oleic (C18:1), linoleic (C18:2), linolenic (C18:3), and arachidonic (C20:4) fatty acids in longissimus dorsi did not vary $(\mathrm{P}>0.05)$ among animals fed diets containing increasing levels of inclusion of cashew bagasse bran in diets, showing that the use of this byproduct brought benefits such as increase in meat:fat ratio, decrease in backfat thickness, and increase in the content of linoleic and arachidonic acids, but they did not interfere in the composition of other fatty acids, contributing to the improvement of pork quality.

\section{Conclusions}

The inclusion of $22.5 \%$ cashew bagasse bran in diets of finishing pigs is recommended because it presents a better meat-to-fat ratio and a higher deposition of linoleic and arachidonic acids in the subcutaneous fat.

\section{Acknowledgments}

The authors thank the Universidade Federal do Rio Grande do Norte and the Conselho National de Desenvolvimento Científico e Tecnológico (CNPq) for the academic master's scholarship grant. 


\section{References}

Albuquerque, N. I.; Contreras, C. C.; Alencar, S.; Meirelles, C. F.; Aguiar, A. P.; Moreira, J. A. and Packer, I. U. 2009. Propriedades da carne e perfil de ácidos graxos do pernil de catetos (Tayassu tajacu) alimentados com torta de babaçu (Orbignya phalerata). Arquivo Brasileiro de Medicina Veterinária e Zootecnia 61:1419-1427.

ABCS - Associação Brasileira de Criadores de Suínos. 1973. Método brasileiro de classificação de carcaça. ABCS, Estrela, RS. 17p. (Publicação Técnica, 2).

Barbosa, H. C. A.; Vieira, A. A.; Almeida, F. Q.; Teixeira, Z. S.; Souza, R. M. and Campos, J. F. 2003. Arquivo Brasileiro de Medicina Veterinária e Zootecnia 55:606-614.

Barbosa, H. C. A.; Vieira, A. A.; Almeida, F. Q.; Teixeira, Z. S.; Souza, R. M. and Campos, J. F. 2003. Qualidade da carcaça de suínos em terminação alimentados com diferentes níveis de restrição alimentar e de energia na dieta. Arquivo Brasileiro de Medicina Veterinária e Zootecnia 55:606-614.

Bligh, E. G. and Dyer, W. J. 1959. A rapid method of total lipid extraction and purification. Canadian Journal of Biochemistry and Physiology 37:911-917.

Bridi, A. M. and Silva, C. A. 2009. Avaliação da carne suína. Midiograf, Londrina.

Farias, L. A.; Lopes, J. B.; Figueirêdo, A. V.; Albuquerque, D. M. N.; Araújo Neto, A. A. and Ramos, L. S. N. 2008. Pseudofruto do cajueiro (Anacardium occidentale L.) para suínos em crescimento: metabolismo de nutrientes e desempenho. Ciência Animal Brasileira 9:100-109.

French, P.; O'Riordan, E. G.; Monahan, F. J.; Caffrey, P. J. and Moloney, A. P. 2003. Fatty acid composition of intra-muscular triacylglycerols of steers fed autumn grass and concentrates. Livestock Production Science 81:307-317.

Fraga, A. L.; Thomaz, M. C.; Kronka, R. N.; Budiño, F. E. L.; Huaynate, R. A. R. and Malheiros, E. B. 2008. Restrição alimentar qualitativa para suínos com elevado peso de abate. Revista Brasileira de Zootecnia 37:869-875.

Hartman, L. and Lago, B. C. 1973. A rapid preparation of fatty methyl esters from lipids. Laboratory Practice 22:475-477.

Lebret, B. and Mourot, J. J. 1998. Caractéristiques et qualité des tissus adipeux chez le porc. Facteurs de variation non génétiques. INRA Production Animal 11:131-143.

Louvandini, H.; McManus, C. M.; Dallago, B. S.; Machado, B. and Antunes, D. A. 2006. Evaluation of carcass traits, non-carcass components and 12th rib analysis of hair sheep supplemented with phosphorus. Revista Brasileira de Zootecnia 35:550-554.

Martin, C. A.; Almeida, V. V. D.; Ruiz, M. R.; Visentainer, J. E. L.; Matshushita, M.; Souza, N. E. and Visentainer, J. V. 2006.
Ácidos graxos poliinsaturados ômega-3 e ômega-6: importância e ocorrência em alimentos. Revista de Nutrição 19:761-770.

Moreira, I.; Voorsluys, T.; Martins, R. M.; Paiano, D.; Furlan, A. C. and Silva, M. A. A. 2007. Efeitos da restrição energética para suínos na fase final de terminação sobre o desempenho, característica de carcaça e poluição ambiental. Acta Scientiarum Animal Science 29:179-185.

Perini, J. A. D. L.; Stevanato, F. B.; Sargi, S. C.; Visentainer, J. E. L.; Dalalio, M. M. D. O.; Matshushita, M. and Visentainer, J. V. 2010. Ácidos graxos poli-insaturados n-3 e n-6: metabolismo em mamíferos e resposta imune. Revista de Nutrição 23:1075-1086.

Pettigrew, J. E. and Esnaola, M. A. 2001. Swine nutrition and pork quality: a review. Journal of Animal Science 79:316-342.

Pinheiro, R. E. E.; Cardoso, E. C.; Klein Júnior, M. H.; Muratori, M. C. S.; Lopes, J. B.; Farias, L. A. and Teixeira, M. D. P. F. 2013. Qualidade da carne de suínos mestiços comerciais e sem raça definida criados em regime intensivo. Revista Brasileira de Saúde e Produção Animal 14:149-160.

Rao, S. V. R.; Raju, M. V. L. N.; Panda, A. K. and Reddy, M. R. 2006. Sunflower seed meal as a substitute for soybean meal in commercial broiler chicken diets. British Poultry Science 47:592-598.

Rhee, K. S.; Ziprin, Y. A.; Ordonez, G. and Bohac, C. E. 1988. Fatty acid profiles of the total lipids and lipid oxidation in pork muscles as affected by canola oil in the animal diet and muscle location. Meat Science 23:201-210.

Riozi C. L.; Araujo, L. F.; Aguiar, E. M.; Pinheiro, L. E. and Nascimento, D. S. 2011. Revisão sobre a potencialidade do pedúnculo do caju na alimentação animal. Tecnologia e Ciência Agropecuária 5:53-59

Rostagno, H. S.; Albino, L. F. T.; Donzele, J. L.; Gomes, P. C.; Oliveira, R. F.; Lopes, D. C.; Ferreira, A. S. and Barreto, S. L. T. 2005. Tabelas brasileiras para aves e suínos: composição de alimentos e exigências nutricionais. 2.ed. UFV, Viçosa, MG.

Santos, R.; Ribeiro, M. D. G.; Farinha, N.; Barradas, A.; Neves, J. A. and Bento, P. 2008. Estudo da influência de diferentes alimentos sobre características quantitativas e qualitativas da gordura em porcos de raça alentejana. Revista de Ciências Agrárias 31:5-16.

Schneeman, B. O. 1982. Pancreatic and digestive function. p.73-83. In: Dietary fiber in health and disease. Springer US.

Watanabe, P. H.; Thomaz, M. C.; Ruiz, U. S.; Santos, V. M.; Masson, G. C.; Fraga, A. L. and Silva, S. Z. 2010. Carcass characteristics and meat quality of heavy swine fed different citrus pulp levels. Arquivo Brasileiro de Medicina Veterinária e Zootecnia 62:921-929.

Zangeronimo, M. G.; Fialho, E. T.; Lima, J. A. F.; Girão L. V. C. and Amaral, N. O. and Silveira, H. 2009. Desempenho e características de carcaça de suínos dos 20 aos $50 \mathrm{~kg}$ recebendo rações com reduzido teor de proteína bruta e diferentes níveis de lisina digestível verdadeira. Ciência Rural 39:1507-1513. 